\title{
PENGARUH KECERDASAN INTERPERSONAL TERHADAP PEMAHAMAN AKUNTANSI DENGAN KEPERCAYAAN DIRI SEBAGAI VARIABEL INTERVENING PADA SISWA JURUSAN AKUNTANSI
}

\author{
Dina Fahma Sari \\ Sawitri Dwi P \\ Universitas Negeri Malang \\ dina04april@gmail.com
}

\begin{abstract}
This research examines the influences of interpersonal intelligence on accounting comprehention which self confidence as intervening variable on student's accounting in SMK Muhammadiyah 1 Pasuruan. The design of this research is explanatory. The variables are interpersonal intelligence $(\mathrm{X})$, self confidence $(\mathrm{Z})$ and an accounting comprehention $(\mathrm{Y})$. The population is amounting 63 students including class X, XI, XII Accounting departement, while the number of samples taken 39 students. Sampling method uses a proportional random sampling. Data collection uses questionnaires. Data analysis uses path analysis. The results of the reseach showed that interpersonal intelligence influences the accounting comprehention by self confidence as intervening variable.
\end{abstract}

Keywords: Interpersonal Intelligence, Self Confidence, Accounting Comprehention

\begin{abstract}
Abstrak: Penelitian ini menguji pengaruh kecerdasan interpersonal terhadap pemahaman akuntansi dengan kepercayaan diri sebagai variabel intervening pada siswa jurusan akuntansi SMK Muhammadiyah 1 Kota Pasuruan. Rancangan penelitian ini merupakan penelitian eksplanasi. Variabel penelitian yang digunakan adalah kecerdasan interpersonal (X), kepercayaan diri (Z) dan pemahaman akuntansi (Y). Populasi penelitian adalah seluruh siswa kelas X, XI, XII jurusan Akuntansi yang berjumlah 63 siswa sedangkan sampel yang diambil berjumlah 39 siswa. Teknik pemilihan sampel menggunakan Propotional Random Sampling. Teknik pengumpulan data menggunakan kuisioner. Analisis dalam penelitian ini menggunakan analisis jalur (path analysis). Hasil dari penelitian menunjukkan bahwa kecerdasan interpersonal berpengaruh terhadap pemahaman akuntansi dengan kepercayaan diri sebagai variabel intervening.
\end{abstract}

Kata Kunci: Kecerdasan Interpersonal, Kepercayaan Diri, Pemahaman Akuntansi

Pemahaman penting bagi siswa karena memahami maksud dari suatu materi dan menangkap maknanya adalah tujuan akhir dari setiap mengajar. Pemahaman memiliki arti yang sangat mendasar yang meletakkan bagian-bagian belajar pada proposisinya. Dalam belajar unsur pemahaman tidak dapat dipisahkan dari unsur psikologi yang lain seperti kecerdasan, motivasi, kepercayaan diri, konsentrasi, dan reaksi maka subjek belajar dapat mengembangkan fakta- fakta, ide-ide atau kemampuan dengan semua unsur tersebut sehingga siswa mampu menata hal-hal tersebut secara bertautan bersama menjadi suatu pola yang logis. Pemahaman juga menghendaki agar siswa dapat 
memanfaatkan bahan-bahan yang telah dipelajari dan dipahami sehingga belajar akan bersifat mendasar. Namun dalam kenyataannya, banyak siswa di sekolah yang melupakan unsur pemahaman ini, diantaranya siswa hanya belajar pada malam hari menjelang ujian pada pagi harinya. Kegiatan belajar yang demikian ini cenderung hanya sekedar mengetahui suatu bahan pelajaran yang dituangkan di kertas ujian, tetapi dalam tiga atau dua hari kemudian, mengenai apa yang dipelajari maka siswa akan lupa terhadap apa yang sudah dipelajari. Hal ini menunjukan siswa tidak memiliki perekat pemahaman yang kuat untuk menginternalisasikan bahan-bahan yang telah dipelajari ke dalam suatu konsep atau pengertian secara menyeluruh.

Pemahaman juga bersifat dinamis sehingga diharapkan pemahaman akan bersifat kreatif, ia akan menciptakan imajinasi-imajinasi dengan pikiran yang tenang. Akan tetapi apabila siswa betul-betul memahami materi yang disampaikan oleh gurunya, maka mereka akan siap memberikan jawaban-jawaban yang pasti atas pertanyaan atau berbagai masalah dalam belajar. Hal ini sangat penting bagi siswa karena memahami maksud dari suatu materi, menangkap maknanya adalah tujuan akhir dari setiap belajar. Pemahaman juga memiliki arti sangat mendasar karena tanpa pemahaman, maka pengetahuan dan sikap tidak bermakna. Pemahaman tidak sekedar tahu akan tetapi juga menghendaki siswa dapat memanfaatkan bahan-bahan yang telah dipahami melalui penelitian, tanggapan, sikap dan perubahan tingkah laku dalam belajar. Semakin dalam pemahaman yang diperoleh siswa pada waktu mempelajari materi untuk pertama kali, makin baik pula prestasi mengingat kembali pada waktu mengerjakan ulangan. Pemahaman akan bersifat kreatif apabila siswa benar-benar memahami suatu materi maka akan siap memberi jawaban yang pasti atas pertanyaan-pertanyaan dalam proses belajar serta mampu mengatasi kesulitan jika dihadapkan dengan soal aplikasi yang lebih rumit.

Berdasarkan studi pendahuluan yang dilakukan oleh Sutrisno dan Eprillia (2008:42) di beberapa SMK baik negeri atau swasta di Surakarta, ditemukan kecenderungan, bahwa siswa sekarang ini cenderung kurang menguasai ketrampilan akademik dasar yang sangat diperlukan untuk menjalani program pendidikan profesional yang baik. Ketrampilan akademik dasar yang dimaksud adalah kemampuan yang memadai dalam menguasai materi yang dapat menunjang mata pelajaran-mata pelajaran lain pada jurusannya, khususnya pada jurusan akuntansi seperti Akuntansi Keuangan, disamping itu juga sebagai mata kuliah pokok yang menjadi bekal bagi peserta didik dalam memasuki dunia kerja. Beberapa faktor penyebab kegagalan itu adalah adanya 
ketakutan maupun tekanan di kalangan sebagian besar siswa dalam menghadapi mata pelajaran konsep keuangan dan hitungan, seperti akuntansi yang tidak sekedar pelajaran hitungan, melainkan juga serangkaian konsep keuangan yang ditata berdasarkan pertimbangan yang berkaitan dengan kaidah-kaidah keuangan yang distandarisasi.

Dasar pemilihan terhadap mata pelajaran akuntansi untuk menjadi objek penelitian, terletak pada realitas bahwa mata pelajaran ini merupakan mata pelajaran pokok sekaligus sebagai "momok" di kalangan SMK (Sutrisno dan Eprilia ,2008:41). Oleh karena itu dipandang sangat diperlukan kajian mendalam tentang terkait solusi yang efektif guna mengantarkan siswa pada pemilikan kompetensi yang sangat diperlukan dalam memahami akuntansi. Berbagai penelitian telah dilakukan guna membantu siswa dalam memahami akuntansi baik itu dari faktor internal (kepribadian, kecerdasan, gaya belajar) dan ekternal (lingkungan, media pembelajaran, sarana) siswa. Diantaranya menjadi fenomena baru di kalangan akademisi terkait faktor internal yang mempengaruhi pemahaman akuntansi siswa diantaranya adalah tingkat kecerdasan (intelligence). Penelitian maupun teori terkait kecerdasan yang sudah terbukti keunggulannya dalam menuju kesuksesan dalam hidup yaitu kecerdasan intelektual, emosional dan spiritual termasuk juga teori baru yaitu kecerdasan majemuk. Namun apakah setiap kecerdasan tersebut mampu memberikan kontribusi dalam pemahaman akuntansi khususnya pada siswa.

Kecerdasan interpersonal dewasa ini telah diperhitungan oleh banyak peneliti menjadi salah satu faktor yang mempengaruhi dan memberikan kontribusi dalam pemahaman siswa. Gardner (2000 dalam Armstrong 2002:21) menyatakan bahwa kecerdasan interpersonal adalah kemampuan untuk memahami dan bekerjasama dengan orang lain, sedangkan Safaria (2005:23) menjelaskan bahwa kecerdasan interpersonal atau kecerdasan sosial sebagai kemampuan dan ketrampilan seseorang dalam menciptakan, membangun relasi, dan mempertahankan relasi sosialnya sehingga kedua belah pihak berada dalam situasi menang-menang atau saling menguntungkan. Kecerdasan interpersonal ini sangat penting karena manusia tidak bisa hidup sendiri. Banyak kegiatan dalam hidup seseorang yang terkait dengan orang lain. Seseorang yang gagal mengembangkan kecerdasan interpersonalnya akan mengalami banyak kegagalan dalam dunia sosialnya. Upaya peningkatan pemahaman siswa saat ini sudah tidak menggantungkan guru sebagai Center of Learning tetapi keterlibatan siswa dalam membangun pengetahuan meskipun tidak menggantikan guru sebagai salah satu sumber informasi belajar. Beberapa pendekatan, strategi dan metode pembelajaran sudah 
dikembangkan yang bertujuan agar siswa benar-benar terlibat dan mampu membangun pemahaman pelajaran selain agar proses pembelajaran berlangsung menyenangkan.

Kecerdasan interpersonal siswa dapat tercermin ketika dia aktif dalam proses belajar mengajar. Sebagian besar metode pembelajaran modern telah melibatkan interaksi lebih dari satu siswa sehingga dibutuhkan kerjasama, interaksi sosial dan sifat kepemimpinan dalam mengatur anggota kelompoknya. Kecerdasan interpersonal yang dimiliki setiap siswa tentunya akan sangat berperan dalam mempermudah kerjasama, diskusi, interaksi antar siswa dan guru dalam proses belajar. Jika berada di lingkup yang lebih luas, kecerdasan interpersonal juga akan menjadi bekal bagi siswa menjadi pribadi yang berani, empati, prososial dalam berinteraksi khususnya ketika mereka mulai berada dalam lingkungan yang lebih luas yaitu masyarakat atau lingkungan kerja

Kepercayaan diri merupakan salah satu variabel kepribadian yang penting dalam mencapai keberhasilan belajar termasuk dalam ranah yang terkecil adalah sebuah pencapaian pemahaman. Lautser (2001 dalam Alsa, 2006: 48) menyatakan bahwa kepercayaan diri merupakan suatu sikap atau perasaan yakin atas kemampuan sendiri sehingga individu yang bersangkutan tidak terlalu cemas dalam setiap tindakan, dapat bebas melakukan hal-hal yang disukai dan bertanggung jawab atas segala perbuatan yang dilakukan, hangat dan sopan dalam berinteraksi dengan orang lain, dapat menerima dan menghargai orang lain, memiliki dorongan berprestasi serta dapat mengenal kelebihan dan kekurangan diri. Berdasarkan ciri-ciri orang yang percaya diri menurut Lauster (2001 dalam Alsa, 2006: 49) yaitu: percaya pada kemampuan sendiri, bertindak mandiri dalam mengambil keputusan, memiliki rasa positif terhadap diri sendiri, serta berani mengungkapkan pendapat.

Siswa yang kurang percaya diri tercermin ketika ia kurang aktif di dalam proses pembelajaran seperti cenderung diam ketika ia tidak mengetahui jawaban atas pertanyaan yang diajukan oleh guru, tidak berani mengungkapkan pendapat, dan tidak yakin atas jawabannya sehingga senantiasa bergantung pada jawaban teman. Hal ini akan berdampak bagi siswa menjadi pribadi yang selalu bergantung pada orang lain dan tidak memiliki kepribadian mandiri sehingga dalam proses pembelajaran tidak akan timbul diskusi aktif dan kompetitif.

Dunia pendidikan di Indonesia baru-baru ini menjelang dilaksanakannya Ujian Nasional (UN) 2010, Dewan Pendidikan Jawa Timur mengimbau kepada seluruh guru untuk dapat menyiapkan mental siswanya. Hal ini perlu dilakukan karena banyak siswa yang cenderung mengalami gangguan psikologis atau stres menjelang UN karena 
ketidakpercayaan diri mereka akan kemampuannya untuk dapat lulus dalam UN. Selain mengawasi psikologis siswa, guru hendaknya juga sering melakukan evaluasi pembelajaran bagi siswa. Melalui proses evaluasi, siswa dapat mengetahui tingkat kemampuan dan besar kesalahan untuk dapat diperbaiki. Jika siswa semakin percaya diri akan kemampuannya, tentu fenomena yang kurang baik akan berkurang pula.

Berdasarkan fenomena UN diatas, kepercayaan diri menjadi dasar yang penting juga dalam menghadapi UN. Namun akan lebih berguna lagi jika kepercayaan diri siswa mulai dilatih ketika berada dalam proses pembelajaran di kelas baik dalam bertanya, menjawab, berdiskusi dan mengemukakan pendapat. Dalam akuntansi, terkadang siswa masih bingung dalam memasukkan akun yang akan dipakai dalam jurnal, salah dalam menyebutkan macam laporan keuangan, bidang-bidang di dalam akuntansi sehingga mereka tidak yakin dalam memberikan jawaban dan cenderung diam apabila guru memberikan pertanyaan. Hal tersebut tentunya akan membuat kesalahan siswa menumpuk dan pemahaman siswa akan cenderung tidak berkembang. Dalam mencapai tingkat pemahaman, siswa dituntut memiliki tingkat kepercayaan diri sehingga mereka akan merasa yakin dalam memberikan jawaban dan percaya bahwa mereka akan lulus UN jika didukung dengan intensitas belajar yang rutin.

Bloom (1979 dalam Arikunto, 2009:17) menyatakan bahwa prestasi belajar merupakan perubahan tingkah laku yang meliputi tiga ranah yaitu ranah kognitif, ranah afektif dan ranah psikomotor. Pemahaman merupakan salah satu taksonomi dari ranah kognitif dimana siswa mengerti tentang sesuatu tetapi tahap mengertinya masih rendah. Faktor-faktor yang mempengaruhi pemahaman siswa diantaranya adalah faktor internal yang meliputi faktor psikologi yang terdiri dari variabel nonkognitif (minat, motivasi, kepercayaan diri dan variabel-variabel kepribadian lainnya) sedangkan kemampuan kognitif terdiri dari kemampuan khusus (bakat) dan kemampuan umum yaitu kecerdasan (kecerdasan intelektual,emosional, spiritual, intrapersonal, interpersonal, musikal, kecerdasan lainnya). Berdasarkan pernyataan teori tersebut maka kecerdasan interpersonal dengan kepercayaan diri sebagai variabel intervening merupakan faktor yang mempengaruhi pemahaman.

Gardner (2000 dalam Armstrong, 2002: 21) menjelaskan kecerdasan interpersonal melibatkan kemampuan untuk memahami dan bekerja dengan orang lain. Kecerdasan Interpersonal mencakup kemampuan membaca orang (misalkan menilai orang lain), kemampuan berteman, dan keterampilan untuk membina hubungan dan bekerja sama dengan orang lain. Safaria (2005: 23) menjelaskan kecerdasan 
Interpersonal atau juga bisa dikatakan sebagai kecerdasan sosial, diartikan sebagai kemampuan dan keterampilan seseorang dalam menciptakan relasi, membangun relasi, dan mempertahankan relasi sosialnya sehingga kedua belah pihak berada dalam situasi menang-menang atau saling menguntungkan. Kecerdasan Interpersonal terbagi atas tiga dimensi yaitu Social Sensitivity, Social insight, dan Social Communication. Social Sensitivity merupakan kemampuan untuk mampu merasakan dan mengamati reaksireaksi atau perubahan orang lain yang ditunjukkannya baik secara verbal maupun non verbal. Social Sensitivity ini meliputi sikap empati dan sikap prososial. Social insight merupakan kemampuan untuk memahami dan mencari pemecahan masalah yang efektif dalam suatu interaksi sosial, sehingga masalah-masalah tersebut tidak menghambat apalagi menghancurkan relasi sosial yang telah dibangun. Social Insight meliputi kesadaran diri, pemahaman situasi sosial dan etika sosial, serta ketrampilan memecahkan masalah. Social communication atau biasa disebut penguasaan keterampilan komunikasi sosial merupakan kemampuan individu untuk menggunakan proses komunikasi dalam menjalin hubungan interpersonal yang sehat. Social Communication meliputi komunikasi efektif dan mendengarkan efektif.

Lauster (2001:14) menyatakan bahwa kepercayaan diri adalah salah satu ciri kepribadian yang mengandung arti keyakinan akan kemampuan diri sendiri, karena mempunyai sikap positif terhadap kemampuannya, sehingga tidak terpengaruh oleh orang lain. Kepercayaan diri merupakan suatu sikap atau perasaan yakin atas kemampuan sendiri sehingga individu yang bersangkutan tidak terlalu cemas dalam setiap tindakan, dapat bebas melakukan hal-hal yang disukai dan bertanggung jawab atas segala perbuatan yang dilakukan, hangat dan sopan dalam berinteraksi dengan orang lain, dapat menerima dan menghargai orang lain, memiliki dorongan berprestasi serta dapat mengenal kelebihan dan kekurangan diri. Menurut Lauster (2001 dalam Zandra 2010:22) terdapat beberapa karakteristik untuk menilai kepercayaan diri individu, diantaranya adalah percaya pada kemampuan diri sendiri, bertindak mandiri dalam mengambil keputusan, memiliki konsep diri yang positif, dan berani mengungkapkan pendapat.

Pemahaman merupakan salah satu jenjang dari ranah kognitif. Ranah kognitif adalah ranah yang mencakup kegiatan mental (otak). Menurut Bloom (1979 dalam Arikunto 2009:117), segala upaya yang menyangkut aktivitas otak adalah termasuk dalam ranah kognitif. Ranah kognitif berhubungan dengan kemampuan berfikir, termasuk didalamnya kemampuan menghafal, memahami, mengaplikasi, menganalisis, 
mensintesis, dan kemampuan mengevaluasi. Menurut Bloom (1979) "Here we are using the tern "comprehension" to include those objectives, behaviors, or responses which represent an understanding of the literal message contained in a communication." Artinya bahwa menggunakan pengertian pemahaman mencakup tujuan, tingkah laku, atau tanggapan mencerminkan sesuatu pemahaman pesan tertulis yang termuat dalam satu komunikasi. Menurut Bloom (1979: 91) terdapat tiga macam pemahaman yaitu pengubahan (Translation), pemberian arti (Interpretation), dan pembuatan ekstrapolasi (Extrapolation).

Adapun keterkaitan konsep pemahaman dan akuntansi bahwa pemahaman menurut para ahli adalah kegiatan mental intelektual yang mengorganisasikan materi yang telah diketahui, sedangkan akuntansi dapat didefinisikan sebagai sistem informasi keuangan yang menghasilkan laporan keuangan kemudian dikomunikasikan kepada pihak-pihak yang berkepentingan mengenai aktifitas ekonomi dan kondisi perusahaan sebagai dasar dalam pengambilan keputusan. Dengan demikian, pemahaman akuntansi adalah suatu kemampuan seseorang untuk mengorganisasikan terkait akuntansi yaitu sistem informasi keuangan yang menghasilkan laporan keuangan kemudian dikomunikasikan kepada pihak-pihak yang berkepentingan mengenai aktifitas ekonomi dan kondisi perusahaan sebagai dasar dalam pengambilan keputusan.

Penelitian dilaksanakan di SMK Muhammadiyah 1 kota Pasuruan karena berdasarkan data Ujian Tengah Semester 2011 kelas X yang dilaksanakan pada bulan September 2011, terdapat lebih dari 60 \% siswa mendapatkan nilai dibawah KKM terutama untuk SK mengelola dokumen transaksi dan menyiapkan jurnal, memahami dan mencatat transaksi dalam persamaan dasar akuntansi. Nilai Ujian Tengah Semester kelas XI, didapatkan hasil bahwa hanya sekitar 5\% siswa yang nilainya berada dibawah KKM khususnya untuk mata pelajaran SK mengelola administrasi pajak dan SK mengelola kartu persediaan. Nilai Ujian Tengah Semester kelas XII, didapat data bahwa 100\% siswa berada di atas KKM terutama untuk mata pelajaran komputer akuntansi. KKM merupakan standar minimal ketuntasan siswa yang pembentuknya adalah prestest, daya dukung seperti kemahiran menggunakan media, dan kompleksitas dari materi yang diajarkan.

Data tambahan berdasarkan wawancara (September, 2011) dengan salah satu guru yang mengajar mata pelajaran akuntansi, hanya terdapat beberapa siswa yang aktif dalam proses belajar, sehingga tidak menimbulkan sebuah diskusi yang hidup dalam rangka mencapai tujuan pembelajaran. Selain itu, tidak terdapat penilaian afektif dan 
psikomotor siswa yang secara khusus mencerminkan tingkat keaktifan siswa dalam kelas. Begitu juga metode pembelajaran kooperatif tidak diterapkan sehingga menjadi salah satu faktor yang membuat kemampuan bekerjasama, interaksi sosial antar siswa tidak berkembang dengan baik yang menyebabkan pelajaran berlangsung membosankan.

Dalam menciptakan pembelajaran yang kooperatif, diperlukan adanya modal dari sisi internal siswa yaitu sebuah kecerdasan interpersonal dan kepercayaan diri. Kecerdasan interpersonal yang dimiliki setiap siswa tentunya akan sangat berperan dalam mempermudah kerjasama, diskusi, interaksi antar siswa dan guru dalam proses belajar khususnya dalam membangun pemahaman. Kepercayaan diri yang kuat juga diperlukan oleh siswa karena dalam bekerjasama perlu adanya keyakinan diri, berani, berpikir positif, yakin dan mampu memahami akuntansi jika didukung juga dengan usaha untuk terus belajar. Berdasarkan fenomena di atas, meskipun sebagian besar siswa jurusan akuntansi memiliki nilai yang baik dalam mata pelajaran akuntansi namun KKM belum bisa mencerminkan tingkat pemahaman akuntansi yang kemudian juga dipengaruhi adanya pembelajaran yang masih bersifat konvensional yang belum melibatkan siswa dalam membangun pengetahuan akuntansi itu secara mandiri. Berdasarkan fenomena diatas, penelitian ini dilakukan untuk mengetahui pengaruh kecerdasan interpersonal terhadap pemahaman akuntansi melalui kepercayaan diri sebagai variabel intervening pada siswa jurusan akuntansi SMK Muhammadiyah 1 kota Pasuruan.

\section{METODE}

Penelitian ini termasuk penelitian eksplanasi (Explanatory reseach) yang menguji hubungan antar variabel yang dihipotesiskan (Sugiono, 2009:11). Penelitian ini menggunakan analisis jalur (path analysis). Teknik analisis jalur adalah teknik yang menganalisis pola hubungan antar dua variabel atau lebih dan bertujuan untuk menguji hipotesis yang menyatakan ada pengaruh antar variabel bebas terhadap variabel intervening, variabel bebas terhadap variabel terikat, serta pengaruh simultan dari variabel bebas, variabel intervening dan variabel terikat. Penelitian ini dilakukan di SMK Muhammadiyah 1 Kota Pasuruan dengan jumlah siswa jurusan akuntansi 63 siswa yang terdiri dari kelas X, XI, XII. Teknik pengambilan sampel yang digunakan adalah Propotional Random Sampling dengan mengambil perwakilan dari setiap kelas sehingga jumlah sampel adalah 39 siswa. 
Penelitian ini menggunakan skala pengukuran Likert yang merupakan metode penskalaan sikap untuk variabel kecerdasan interpersonal dan kepercayaan diri yang menggunakan distribusi respon sebagai dasar penentuan sikap nilai skalanya dengan menggunakan repson yang dikategorikan kedalam empat macam kategori jawaban yaitu: selalu (S), sering (SR), kadang (KD) dan tidak pernah (TP). Skala Likert meniadakan kategori jawaban yang di tengah yaitu ragu-ragu (R) berdasarkan tiga alasan yaitu kategori undecided yang berarti ganda, dapat diartikan belum dapat memutuskan atau memberi jawaban (menurut konsep aslinya dapat diartikan netral, setuju-tidak setuju, atau bahkan ragu-ragu). Sedangkan pemahaman akuntansi, menggunakan empat kategori jawaban yaitu Sangat Setuju (SS), Setuju(S), Tidak Setuju (TS), dan Sangat Tidak Setuju (STS).

Hubungan antara variabel bebas, variabel terikat dan variabel intervening dapat ditunjukkan pada gambar berikut.

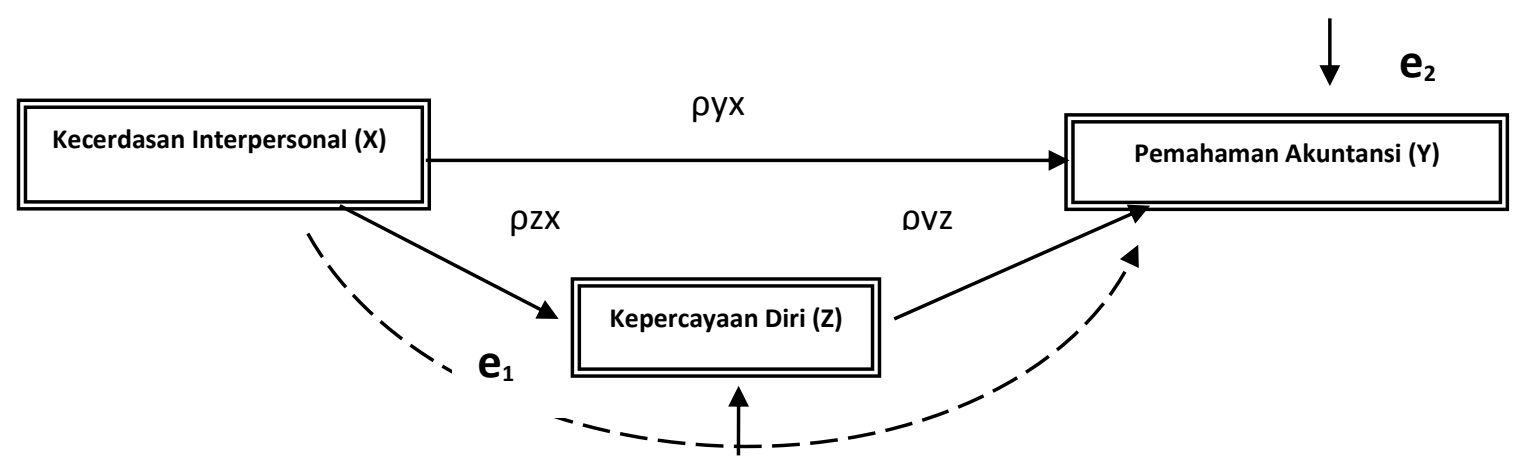

$\rho y-z-x$

Gambar 1. Hubungan Variabel Bebas dan Variabel Terikat

Model tersebut dapat dinyatakan dalam bentuk persamaan, sehingga membentuk persamaan sebagai berikut:

1. $Z=\rho z x \cdot X+e 1$

2. $\quad \mathrm{Y}=\rho \mathrm{yx} \cdot \mathrm{X}+\rho \mathrm{yz} \cdot \mathrm{Z}+\mathrm{e} 2$

Nilai dalam koefisien jalur $(\rho)$ tersebut menunjukkan pengaruh langsung variabel bebas terhadap variabel terikat.

Untuk menguji pengaruh variabel $\mathrm{X}, \mathrm{Z}$ dan $\mathrm{Y}$ digunakan uji statistik $\mathrm{t}$ yang menggunakan bantuan SPSS Windows 16.0. Untuk mengetahui signifikansi analisis jalur dapat dengan membandingkan antara nilai probabilitas 0,05 dengan nilai probabilitas sig dengan dasar pengambilan jika nilai probabilitas $0,05>$ nilai probabilitas sig, maka Ho diterima dan Ha ditolak, berarti tidak signifikan sedangkan jika nilai probabilitas $0,05<$ nilai probabilitas sig, maka Ho ditolak dan Ha diterima, berarti signifikan. 
Pengaruh tidak langsung variabel bebas terhadap variabel terikat melalui variabel intervening yaitu diperoleh melalui perkalian nilai pengaruh langsung (koefisien beta terstandarisasi) pada masing-masing persamaan. Dalam penelitian ini untuk mencari pengaruh variabel bebas $(\mathrm{X})$ dan variabel terikat $(\mathrm{Y})$ melalui variabel intervening $(\mathrm{Z})$ $\operatorname{adalah}$ PTL $(X-Y)=\rho z x \times \rho y z$

\section{HASIL DAN PEMBAHASAN}

\section{Hasil}

Analisis jalur dalam penelitian ini dilakukan dengan menggunakan regresi linier sederhana. Analisis regresi linier sederhana digunakan untuk melihat pengaruh langsung variabel kecerdasan interpersonal terhadap pemahaman akuntansi, kecerdasan interpersonal dengan kepercayaan diri, kepercayaan diri terhadap pemahaman akuntansi, serta untuk melihat pengaruh tidak langsung variabel kecerdasan interpersonal terhadap pemahaman akuntansi dengan kepercayaan diri sebagai variabel intervening .

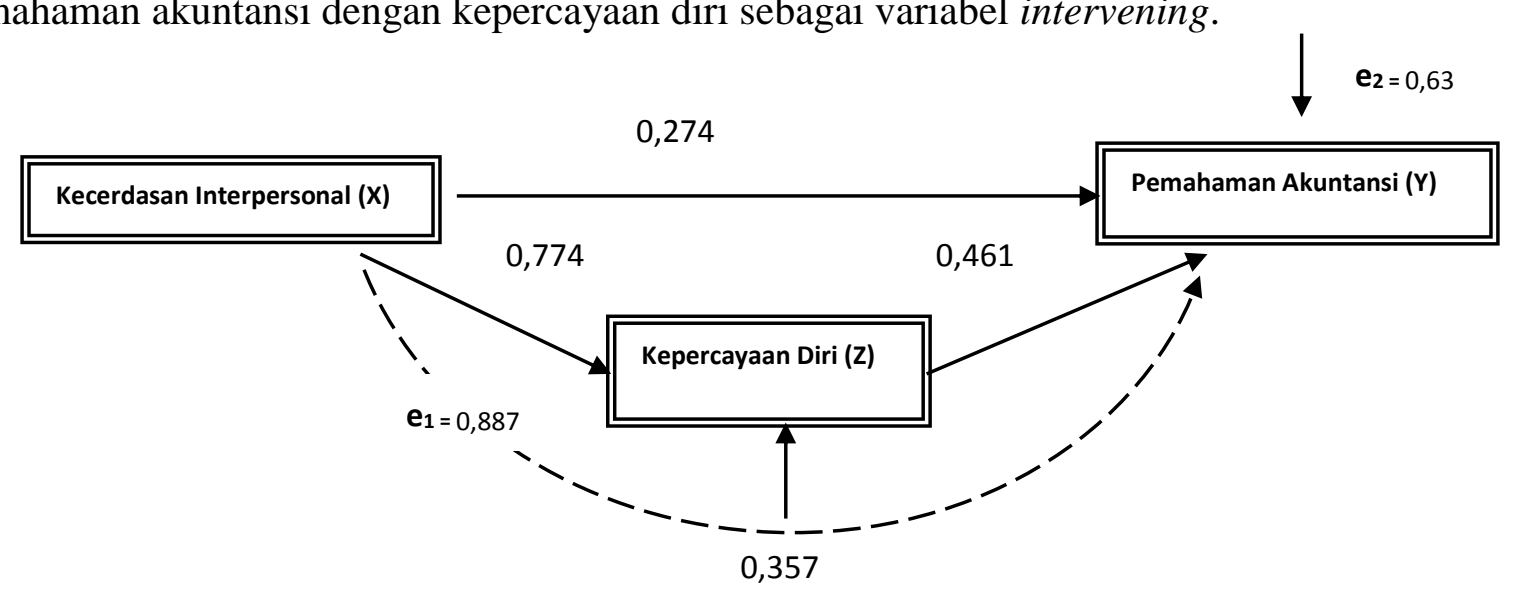

Gambar 2. Analisis Jalur Variabel Bebas ke Variabel Terikat

Model tersebut dapat dinyatakan dalam bentuk persamaan berikut.

$$
\begin{aligned}
& Z=\rho z x \cdot X+\mathrm{e} 1 \\
& Z=0,774+0,887 \\
& Y=\rho y x \cdot X+\rho y z \cdot Z+e 2 \\
& Y=0,274+0,461+0,633
\end{aligned}
$$


Tabel 1. Hasil Regresi Keceerdasan Interpersonal terhadap Pemahaman Akuntansi

\begin{tabular}{|c|c|c|c|c|}
\hline Variabel & $\begin{array}{c}\text { Unstandardized } \\
\text { Coefficients }\end{array}$ & $\begin{array}{c}\text { Standardized } \\
\text { Coefficients }\end{array}$ & $\mathbf{t}$ & sig \\
\hline $\begin{array}{l}\text { Kecerdasan } \\
\text { interpersonal }\end{array}$ & 0.520 & 0.274 & 4.267 & 0.000 \\
\hline $\begin{array}{l}\text { Adjusted R sq } \\
\text { R square } \\
\text { Konstanta }\end{array}$ & $\begin{array}{l}0,312 \\
: 0,330 \\
: 24,258\end{array}$ & & & \\
\hline \multicolumn{5}{|c|}{ Sumber: (Data diolah) } \\
\hline \multicolumn{5}{|c|}{$\begin{array}{l}\text { Berdasarkan tabel diatas, konstanta sebesar } 24,258 \text { menyatakan bahwa jika tidak ada } \\
\text { kenaikan nilai dari variabel kecerdasan interpersonal }(\mathrm{X}) \text {, maka nilai pemahaman akuntansi } \\
\text { (Y) adalah } 24,258 \text {. Terlihat bahwa pada kolom sig (signifikan) diperoleh nilai } 0,000 \text { untuk } \\
\text { variabel kecerdasan interpersonal. Nilai } 0,000<\text { nilai probabilitas } 0,05 \text { dan pada kolom } t \\
\text { menunjukkan variabel kecerdasan interpersonal thitung } 4,267>t_{\text {tabel }} 2,022 \text {. Berdasarkan hasil } \\
\text { analisis di atas dapat dinyatakan bahwa koefisien analisis jalur adalah signifikan. Kecerdasan } \\
\text { interpersonal berpengaruh langsung dan signifikan terhadap pemahaman akuntansi siswa } \\
\text { jurusan akuntansi SMK Muhammadiyah } 1 \text { kota Pasuruan. }\end{array}$} \\
\hline
\end{tabular}

Tabel 2. Hasil Regresi Kecerdasan Interpersonal terhadap Kepercayaan Diri

\begin{tabular}{lcccc}
\hline Variabel & $\begin{array}{c}\text { Unstandardized } \\
\text { Coefficients }\end{array}$ & $\begin{array}{c}\text { Standardized } \\
\text { Coefficients }\end{array}$ & T & Sig \\
\hline $\begin{array}{l}\text { Kecerdasan } \\
\text { interpersonal }\end{array}$ & 1,146 & 0,154 & 7,427 & 0.000 \\
\hline
\end{tabular}

Adjusted R square: 0,558

R square : 0,559

Konstanta : :31,138

Sumber: (Data diolah)

Konstanta sebesar 31,138 menyatakan bahwa jika tidak ada kenaikan nilai dari variabel kecerdasan interpersonal (X), maka nilai kepercayaan diri (Z) adalah 31,138. Terlihat bahwa pada kolom sig (signifikan) diperoleh nilai 0,000 untuk variabel kecerdasan interpersonal. Nilai $0,000<$ nilai probabilitas 0,05 dan pada kolom $t$ menunjukkan $t_{\text {hitung }}$ untuk variabel kepercayaan diri 7,427>tabel 2,022. Berdasarkan hasil analisis di atas dapat dinyatakan bahwa koefisien analisis jalur adalah signifikan. Kecerdasan interpersonal berpengaruh langsung dan signifikan terhadap kepercayaan diri siswa jurusan akuntansi SMK Muhammadiyah 1 kota Pasuruan. 
Tabel 3. Hasil Regresi Kepercayaan Diri terhadap Pemahaman Akuntansi

\begin{tabular}{lcccc}
\hline Variabel & $\begin{array}{c}\text { Unstandardized } \\
\text { Coefficients }\end{array}$ & $\begin{array}{c}\text { Standardized } \\
\text { Coefficients }\end{array}$ & $\mathbf{t}$ & Sig \\
\hline $\begin{array}{l}\text { Kepercayaan } \\
\text { diri }\end{array}$ & 0,282 & 0,461 & 3,160 & 0.003 \\
\hline
\end{tabular}

Adjusted R square: 0,191

$\mathrm{R}$ square

$: 0,213$

Konstanta

$: 25,146$

Sumber: (Data diolah)

Konstanta sebesar 25,146 menyatakan bahwa jika tidak ada kenaikan nilai dari variabel kepercayaan diri (Z), maka nilai pemahaman akuntansi (Y) adalah 25,146. Koefisien regresi sebesar 0,461 menyatakan bahwa setiap penambahan satu skor atau nilai kepercayaan diri akan memberikan kenaikan skor senilai 0,461. Terlihat bahwa pada kolom sig (signifikan) diperoleh nilai 0,003 untuk variabel kepercayaan diri. Nilai $0,003<$ nilai probabilitas 0,05 dan pada kolom $t$ menunjukkan $t_{h i t u n g}$ untuk variabel pemahaman akuntansi 3,160 > $t_{\text {tabel }}$ 2,022. Berdasarkan hasil analisis di atas dapat dinyatakan bahwa koefisien analisis jalur adalah signifikan. Kepercayaan diri berpengaruh langsung dan signifikan terhadap pemahaman akuntansi siswa jurusan akuntansi SMK Muhammadiyah 1 kota Pasuruan. Pengaruh tidak langsung variabel bebas terhadap variabel terikat melalui variabel intervening seperti model lintasan di atas, diperoleh rumus sebagai berikut.

$$
\begin{aligned}
& \text { PTL }(X-Y)=\rho_{z x} \times \rho_{y z} \\
& \operatorname{PTL}(X-Y)=0,774 \times 0,461=0,357
\end{aligned}
$$

Berikut disajikan rangkuman koefisien jalur, pengaruh langsung, pengaruh tidak langsung dan pengaruh total.

Tabel 4. Rangkuman Koefisien Jalur, Kontribusi Langsung, Tidak Langsung, Kontribusi Total

\begin{tabular}{llcccc}
\hline Variabel & $\begin{array}{l}\text { Koefisien } \\
\text { Jalur }\end{array}$ & Langsung & $\begin{array}{c}\text { Tidak } \\
\text { Langsung }\end{array}$ & Total & $\begin{array}{c}\text { Kontribusi } \\
\text { Bersama }\end{array}$ \\
\cline { 3 - 5 } & 0,274 & 0,274 & - & 0,274 & - \\
$\mathrm{X} \rightarrow \mathrm{Y}$ & 0,774 & 0,774 & - & 0,774 & - \\
$\mathrm{X} \rightarrow \mathrm{Z}$ & 0,461 & 0,461 & - & 0,461 & - \\
$\mathrm{Z} \rightarrow \mathrm{Y}$ & 0,887 & - & - & - & - \\
$\mathrm{e}_{1}$ & 0,633 & - & - & - & - \\
$\mathrm{e}_{2}$ & 0,356 & - & 0,357 & 0,357 & - \\
\hline $\mathrm{X} \rightarrow \mathrm{Z} \rightarrow \mathrm{Y}$ & & & &
\end{tabular}

Sumber: (Data diolah)

Berdasarkan hasil perhitungan diatas maka terdapat pengaruh kecerdasan interpersonal (X) terhadap pemahaman akuntansi (Y) melalui kepercayaan diri (Z) sebagai variabel intervening 
pada siswa jurusan akuntansi SMK Muhammadiyah 1 kota Pasuruan. Hal ini berdasarkan pengaruh tidak langsung kecerdasan interpersonal $(\mathrm{X})$ terhadap pemahaman akuntansi $(\mathrm{Y})$ dengan kepercayaan diri (Z) sebagai variabel intervening memberikan kontribusi yakni sebesar 0,357 sehingga hipotesis dari penelitian ini diterima yaitu kecerdasan Interpersonal dapat berpengaruh langsung terhadap pemahaman Akuntansi dan juga berpengaruh tidak langsung yaitu melalui variabel intervening yaitu kepercayaan diri. Pemahaman akuntansi akan meningkat jika dipengaruhi oleh kecerdasan interpersonal secara langsung dan juga mampu diperkuat jika terdapat kepercayaan diri. Semakin tinggi kecerdasan Interpersonal dan kepercayaan diri maka akan meningkatkan pemahaman akuntansi.

\section{Pembahasan}

Hasil penelitian menunjukkan bahwa terdapat pengaruh kecerdasan interpersonal terhadap pemahaman akuntansi dengan kepercayaan diri sebagai variabel intervening pada siswa jurusan Akuntansi SMK Muhammadiyah 1 kota Pasuruan. Pemahaman seorang siswa tentunya dipengaruhi oleh banyak faktor baik dari faktor internal maupun eksternal. Faktor internal terkait dalam diri siswa sendiri diantaranya adalah kecerdasan dan kepercayaan diri. Kecerdasan interpersonal adalah salah satu kecerdasan yang berkaitan dengan cara seseorang untuk menjalin, membina, menciptakan mempertahankan hubungan dengan orang lain dalam rangka mendapatkan sebuah informasi, memecahkan masalah, menciptakan sebuah relasi sosial yang tidak saling merugikan. Guru dan seluruh siswa saling berhubungan dan berinteraksi satu dengan yang lainnya terkait dengan pelajaran yang sedang berlangsung. Interaksi sosial yang kreatif, aktif dan nyaman akan membuat semua siswa menjadi senang di dalam kelas dan memudahkan mereka memahami pelajaran. Pemahaman siswa tentang akuntansi dapat dilihat ketika mereka mampu menjelaskan, menguraikan, mendeskripsikan dan membedakan kepada teman sekelas, guru maupun ketika berdiskusi.

Pengaruh kecerdasan interpersonal terhadap pemahaman akuntansi akan diperkuat jika setiap siswa juga memiliki kepercayaan diri yang tinggi yang terlihat kemampuannya dalam mengambil keputusan secara mandiri, berani mengungkapkan pendapat dan memiliki rasa positif terhadap dirinya sendiri. Siswa yang sudah memiliki kecerdasan interpersonal dan kepercayaan diri yang tinggi akan mampu menjelaskan apa yang ada dipikirnya dengan yakin bahwa penjelasannya adalah benar dan tidak memiliki rasa canggung dalam mengungkapkan pendapat karena ia mampu bertindak mandiri. Pemahaman adalah tujuan akhir dari pengajaran dan yang juga menjadi dasar dalam mencapai tahap yang tingkatannya lebih tinggi. Pemahaman dasar yang kuat tanpa didasari membantu siswa agar tidak akan 
mengalami kesulitan mencapai ranah kognitif yang lebih tinggi yaitu dalam mengerjakan, mengaplikasi, menganalisis terkait akuntansi. Siswa yang memiliki kecerdasan interpersonal yang tinggi merasa nyaman walaupun berada di antara orang-orang yang memiliki latar belakang yang berlainan, baik berada dalam usia, kebudayaan dan tingkat sosial, juga akan membuat orang-orang disekitarnya merasa nyaman dan santai dengan keberadaaan dirinya. Ketrampilan memecahkan sebuah persoalan meerupakan salah satu ciri dari siswa yang memiliki kecerdasan interpersonal. Ia akan menggunakan strategi kolaborasi melibatkan kerjasama antar teman untuk bersama-sama dalam memecahkan sebuah permasalahan dan mencari pemecahan yang menguntungkan semua pihak. Namun dalam memecahkan suatu permasalahan, setiap siswa memiliki tingkat pemahaman yang berbeda-beda terhadap permasalahan tertentu, tergantung dari segi kognitif maupun non kognitif siswa.

Siswa yang memahami sesuatu memudahkan ia dalam memecahkan suatu persoalan bahkan persoalan yang agak sulit sekalipun karena secara mendasar ia sudah paham akar permasalahan tersebut. Hal ini akan semakin menguntungkan jika siswa tersebut memiliki kecerdasan interpersonal yang tinggi sehingga apabila ada sebuah permasalahan ia akan mampu memecahkannya secara kolaborasi atau kerjasama dengan temannya. Begitu juga jika hal ini dikaitkan dengan pemahaman terhadap akuntansi terutama akuntansi yang bersifat mendasar atau umum yang sebagian besar siswa belum paham benar terkait konsep tersebut. Dengan adanya faktor kecerdasan interpersonal maka siswa mampu memecahkan permasalahan terkait akuntansi dengan cara kerjasama dengan temannya tanpa ada yang merasa dirugikan. ia akan menjelaskan kepada temannya dengan komunikasi yang efektif dan mendengarkan dengan secara kritis apa yang diungkapkan oleh temannya tersebut terkait akuntansi.

Tinggi rendahnya kepercayaan pada diri seseorang dapat diketahui dari beberapa ciri, salah satunya adalah berani mengungkapkan pendapat yang artinya individu mampu mengutarakan sesuatu dalam diri yang ingin diungkapkan kepada orang lain tanpa paksaan. Jika individu memiliki kecerdasan interpersonal yang tinggi maka ia akan mudah bergaul dengan orang lain meskipun memiliki latar belakang yang berbeda serta ia akan mampu menggungkapkan sebuah pendapat tanpa merasa malu atau canggung.

Salah satu ciri seorang siswa memahami suatu materi adalah ketika siswa tersebut mampu menjelaskan, membedakan dan mendeskripsikan materi yang sudah diajarkan di dalam kelas baik itu nonverbal maupun verbal. Dalam menjelaskan yang apa sudah diajarkan di dalam kelas, siswa dituntut yakin dan percaya bahwa yang diungkapkan adalah benar dan tanpa ada pengaruh maupun bantuan dari orang lain. Ia akan bertindak mandiri dalam 
mengambil sebuah keputusan, terutama hal ini terjadi ketika siswa dihadapkan pada pertanyaan-pertanyaan terkait akuntansi yang diajukan oleh guru. Segala macam pengaruh dari temannya yang dirasa lebih pandai dari dia, tidak membuat siswa tersebut merubah jawaban atau argumennya karena yakin bahwa jawabannya benar. Berani dalam menggungkapkan pendapat secara jelas juga menjadi indikator bahwa ia memahami pelajaran tersebut.

Hasil telaah yang dapat dinyatakan bahwa dalam mencapai tingkat pemahaman siswa khususnya dibidang akuntansi terdapat faktor internal yang mempengaruhi yaitu meliputi faktor psikologi yang terdiri dari variabel nonkognitif (minat, motivasi, kepercayaan diri dan variabel-variabel kepribadian lainnya) sedangkan kemampuan kognitif terdiri dari kemampuan khusus (bakat) dan kemampuan umum yaitu kecerdasan (kecerdasan intelektual,emosional, spiritual, intrapersonal, interpersonal, musikal, kecerdasan lainnya). Hasil penelitian ini (2012) telah berhasil mengkorfirmasi ulang teori Bloom (1979 dalam Arikunto, 2009:17) yang menyatakan bahwa prestasi belajar merupakan perubahan tingkah laku yang meliputi tiga ranah yaitu ranah kognitif, ranah afektif dan ranah psikomotor. Pemahaman merupakan salah satu taksonomi dari ranah kognitif dimana siswa mengerti tentang sesuatu tetapi tahap mengertinya masih rendah. Faktor-faktor yang mempengaruhi pemahaman diantaranya adalah faktor internal yang meliputi faktor psikologi yang terdiri dari variabel nonkognitif yaitu kepercayaan diri dan kemampuan umum yaitu kecerdasan interpersonal.

\section{SIMPULAN}

Berdasarkan hasil penelitian dan pembahasan yang telah diuraikan, dapat ditarik kesimpulan bahwa terdapat pengaruh kecerdasan interpersonal terhadap pemahaman akuntansi dengan kepercayaan diri sebagai variabel intervening pada siswa jurusan akuntansi SMK Muhammadiyah 1 kota Pasuruan. Berdasarkan hasil penelitian dan kesimpulan tentang penelitian ini, berikut diajukan beberapa saran bagi peneliti selanjutnya, (1) menambah variabel lain selain kecerdasan interpersonal dan kepercayaan diri apabila akan mengambil masalah serupa karena berdasarkan sumber yang ada terbukti kedua faktor tersebut hanya mewakili faktor internal yang mempengaruhi pemahaman akuntansi siswa. Menurut Slameto (2003:55), faktor yang berpengaruh terhadap prestasi belajar termasuk pemahaman siswa yaitu: (a) faktor intern berupa faktor jasmaniah, faktor psikologis, faktor kelelahan dan (b) faktor ekstern: faktor lingkungan keluarga, faktor lingkungan sekolah, faktor lingkungan sekolah; (2) indikator pernyataan pemahaman akuntansi dapat diukur sesuai dengan materi 
akuntansi yang diajarkan di kelas akuntansi sehingga setiap kelas memiliki tingkat pemahaman akuntansi yang berjenjang sesuai yang diajarkan; (3) teknik pengumpulan data dapat ditambah seperti dengan menggunakan teknik wawancara sehingga data yang terkumpul dapat lebih lengkap dan mendalam.

\section{DAFTAR RUJUKAN}

Alsa, Asmadi. 2006. Hubungan Antara Dukungan Sosial Orang Tua Dengan Kepercayaan Diri Remaja Penyandang Cacat Fisik. Semarang: Jurnal Psikologi. No.1. 47-48.

Arikunto. 2009. Dasar-Dasar Evaluasi Pendidikan Edisi Revisi. Jakarta: Bumi Aksara.

Armstrong, Thomas. (2002). Seven Kids of Smart. Menemukan dan Meningkatkan Kecerdasan Berdasarkan Teori Multiple Intellegence. Jakarta: Penerbit Gramedia

Bloom, Benyamin et all. 1979. Taxonomy of Education Objectives, Cognitive Domain. London: Longman Group Ltd.

Lauster, P. 2001. Tes Kepribadian. Jakarta: Sinar Grafika Offset

Safaria, T. 2005. Interpersonal Intellegence: Metode Pengembangan Kecerdasan Interpersonal Anak. Yogyakarta:Amara Books.

Sugiono. 2009. Metode Penelitian Pendidikan. Bandung: Alfabeta.

Sutrisno, Budi dan Eprilia, Ummi Hany. 2008. Perilaku Koping dalam Menghadapi Mata Pelajaran Akuntansi pada Siswa SMK Batik I Surakarta. Varia Pendidikan, Vol. 20, No. 1, Juni 2008.Program Studi Pendidikan Ekonomi Akuntasi - FKIP Universitas Muhammadiyah Surakarta. 